\title{
A Common Traditional Woman's Life Story
}

\author{
Heiner Fabián Goméz García \\ Universidad Pedagógica y Tecnológica de Colombia \\ heiner115-32@hotmail.com
}

Erika Natalia Morales Parada

Universidad Pedagógica y Tecnológica de Colombia

enatm23@gmail.com

My story took place in the Yunnan's countryside in China in 1919. Yunnan is located in the southeast of China. It is a beautiful place that even visitors call "the garden of Eden" due to its wonderful scenery.

I am Feng Xi-Wang, and my name means hope in English and esperanza in Spanish. I am 15 years old, and I love to study. I'm very interested in making women' voices heard, which means, I'm against my traditions because women are not allowed to speak. My father is called Feng Gang, which means a hard, rigid, and strong man. He is one of the most important farmers in Yunnan, China. He has already planned my life, and I don't agree with him.

I have been studying secretly because my father just wants me to learn how to do housework and how to be a wife and a mother. But I already know what I want for my life. When I tried to talk with my father about what I wanted to study, he always says "No, you cannot!" That's why my plans are, first, leave home and get away from my country. Second, get a place where to stay. Third, get a part-time job, and fourth, look for a law school to study and help the women from my country. When I do it, I will totally be a wild horse of a woman. Today, I tried to talk with my father again, but he just shouted "If you are going to keep saying the same, you just get out!"

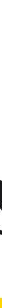


I was very disappointed with my father and with the place I had been born. I needed to make a decision right now. So, I went to my best friend's house. She is called Yan Xia, which means somebody who lives in seclusion. She is 16 years old, and she is already married. Her husband is called Yan Yan, and he is 32 years old. He is also a farmer. Xia's father decided on the man that her daughter needed to marry. By the time I went to visit Xia, two months had passed since they had gotten married. That was my first visit to her after her marriage.

When I talked with her and asked her about how she was, she said "I'm fine. I feel I'm falling in love. He is a good man", but I didn't feel she was being honest with her feelings. When I told her my plan, she said "I heard that your father is asking for your fiancé to come back sooner. So, once he comes back, your wedding is going to be celebrated too." I was in shock, and I said "That's not going to happen to me. Actually, I have come to say goodbye. I cannot accept my father's desires, and I'm going to leave my house tonight." At the beginning, she was worried about me, but after a long conversation, she supported me. I needed to hear it from somebody. Minutes later, I said goodbye to my friend to go back to my house.

After I left, Xia had to go visit her aunt. Because of time, she had to take the shortcut through the Erhai Lake. Once she was about to get on the canoe, she looked through the bushes, and two people were kissing at the lakeside. She looked down and found Yan Yan's carved necklace. She was surprised because she also heard noises and whispers. Right away, she got curious and started walking and looking for the noises she had heard. Getting closer and closer, she realized that all the noises she had been hearing belonged to her husband and me. When she looked at that scene, she just ran away to her house. I wished she had done something at that moment.

I took more hours to arrive home. Meanwhile, my father was drinking his tea, and somebody knocked the door. It was a mailman with a letter for Mr. Feng. Once he read the letter, his teacup fell down. It said "XIWANG IS GOING TO LEAVE TONIGHT WITH A MARRIED MAN."

When I got home, I ate my dinner. With a mix of feelings, I went to my bedroom. Minutes later, my mother and father barged into my bedroom to see and check up on me. They saw me sleeping in my bed. Once my parents left my bedroom, right away, I got up off of the bed. I put my clothes, money, and notebooks in my luggage. When I got out of the house and jumped the wall, I saw many servants. They took me and brought me into the house. My father was waiting at the front door.

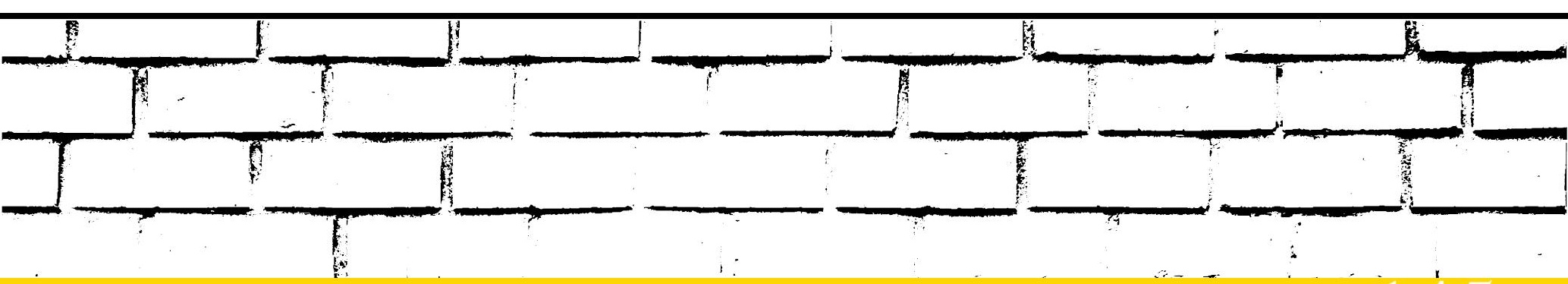


Once he saw me, he said "you have shamed our family, the Fengs! I raised you to be obedient. That was your obligation! Now, take her and lock her up in her bedroom!" He didn't give me the chance to explain. I tried to talk with my mother, but my father didn't allow her to talk to me. Nobody was allowed to speak to me.

While I was locked up in my bedroom, my fiancé miraculously arrived. His name was Yi, which means firm like a stone and determined as an emperor. He was 24 years old by that time...We could talk, and I tried to persuade him about not getting married, but he didn't listen to me. In fact, what I said to him made things worse! The wedding date was moved forward by two days... Once the wedding was carried out, my father bought the house next door with the trellises windows for us. Yi was a good husband, but he didn't allow me to leave home. So, the only way I could see the outside was through the windows. I spent many hours lost in my thoughts, thinking about what I could do if I could leave my house, and about... What happened that day! I could not understand...

One day, finally, my mother came to visit me, and I didn't hesitate about asking her for the fateful day. She told me about the message in the letter my father got that night. I realized what had happened, and I couldn't believe that Xia had done that to me. I just had told her my plans. I wrote a letter demanding an explanation about what she did to me. Her answer was "Because you and my husband cheated on me, best friend!" I had no words. I could not believe how stupid she was... That day, while I was walking to my house, I met her husband on the way. He took me against my will, and he sexually abused me. I could not do anything to avoid it. He was stronger than I. I could never forgive that couple... but my father was the worst... He didn't allow me to speak, he was never willing to listen to me...

The end... 